\title{
Emergence of New Snail Species and Cercariae on Jakara Dam
}

\author{
Rabi Suraj Duwa \\ Nigeria Police Academy, Wudil, Kano state
}

\begin{abstract}
Fresh water snails in Jakara dam were investigated for different types of cercariae. Snails were collected from different parts of the dam in Minjibir, Ugoggo and Gezawa local government area between October 2016 and January 2017 by hand picking only and placed separately in compartmented petridishes for cercarial shedding. Result showed that twenty one snail species from two families comprising Lymnaeidae and Planorbidae were encountered. Bulinus species collected are B. globosus morelet, B. reticulatus, B. truncatus rohlfsi, B truncatus truncatus Egypt, B jousseammei, B. succinoides and B. camerunensis. Fourteen species of Lymnea were encountered from different parts of the dam. Lymnea species encountered are Peplimnea affinus ((Küster, 1862), Lymnea (Pseudosuccina) columella, L. natalensis, Lymnaea ollula, L. tormentosa, L.auricularis rubiginosa with one of them shedding more than a hundred cercariae. Most of these lymnea species cannot be identified or named. Twelve different types of cercaria were discovered but only nine of them were presumably identified as Virgulate, Ubiquita, Gymnocephalus, Amphistome, Echinostome, Armatae cercaria, Parapleurolophocercous cercariae, Ornatae and Fucocercus cercaria (videos of swimming available), three of them cannot be identified. Lymnea species from Bangare showed the most infection with one of them shedding more than a hundred cercariae. There was no schistosome cercariae. This is the first time more than three types of cercariae were observed in Jakara dam. Data analysis was done descriptively. The presence of these new types of cercariae may not be unconnected with the presence of different species of Lymnea encountered in the water body and may mean a new trend in trematode infection.
\end{abstract}

Keywords: Bulinus species, Cercariae, Jakara dam, Kano state, Lymnea species.

\section{Introduction}

Most dams were constructed to achieve food security, through river impoundment, to provide sufficient water for year-round irrigation. Within a short time the dams started harbouring fresh water snails that can transmit diseases by serving as intermediate hosts. The rates of infection with Schistosomiasis begins to increase. Fascioliasis was also observed. These two diseases were transmitted by Bulinid, Biomphalaria and Lymnoid snails. In Jakara dam Bulinus globosus , Biompharia glabrata and Lymnea natalensis are the only snails found as intermediate hosts until recently when many other species of Bulinus were encountered in the other parts of Jakara dam. It was the result of this previous study that motivated the present study. The roles of dams in the transmission of schistosomiasis and fascioliasis cannot be over-emphasized. Ofoezie (2002) reported that 20(43\%) out of the 47 investigated dams harboured Bulinus globosus and / or Biomphalaria pfeifferi, the local intermediate host species for Schistosoma haematobium and S. mansoni, respectively. Most studies carried out in these dams has only emphasized their roles in the transmission of schistosomiasis (Duwa and Oyeyi,2009; Ofoezie et al., 1991, 1996). Schistosomiasis is not the only disease transmitted by freshwater snails found in dams that can affect man. Lymnea species are the intermediate hosts of Fascioliasis. Fascioliasis is a parasitosis mainly infecting cattle, but it is now considered to be an emergent disease of humans in many countries all over the world (Mas-Coma, 2005). L. natalensis transmits Fasciola parasites to animals and man causing fascioliasis (Utzinger and Tanner, 2000; Dida et al., 2014). It is widespread in tropical Africa, but it is rare in the Northeast coastal area (Appleton et al., 2009). This disease is endemic in 61 countries and has become a food-borne infection of public health importance in parts of the world such as the Andean Highlands of Bolivia, Ecuador, and Peru; the Nile Delta of Egypt; and Northern Iran. It is estimated that more than 180million people are at risk of infection, and infection rates are high enough to make fascioliasis a serious public health concern WHO, (1998). Fasciolosis due to $F$. gigantica has been reported in several parts of Africa ( Abebe et al,2010) and Nigeria (Umar et al, 2009). Elelu et al (2016) reported the presence of positive cases of Fasciola gigantica in Kwara state. In other places where this disease was reported Lymnea species other than Lymnea natalensis has been identified as the intermediate host. Lymnea natalensis has been reported in Northern Nigeria (Betterton et al., 1988; Duwa and Oyeyi, 2009;Duwa,2017) especially in the Southwest region (Ndifon and Ukoli, 1989), with habitat fragmentation that has resulted in their patchy distribution in lakes, dams, canals, ponds and rivers. Despite the fact that this snail is well distributed in Nigeria with wide geographical range, there is identification and information problem of the different species in the different water bodies if there is any record of their existence in the first place. Since there is no knowledge or record of their existence control efforts to limit disease transmission through vector control will not be possible. 


\section{Material and Methods}

2.1 Study area: This study was carried out in five parts of Jakara dam, Bangare and Danmadahun in Gezawa local government area; Yadakunya in Ungoggo local government area, Fako and Kwata both in Wasai, Minjibir local government area of Kano state. Wasai (Latitude N12 $09.589^{\prime} 8^{0}$ and Longitude $40.422 ' \mathrm{E}$ ), Fako (Latitude $\mathrm{N} 12^{\circ} 08.940^{\prime}$ and Longitude $8^{0} 39.113^{\prime} \mathrm{E}$ ), Bangare (Latitude N12 $07.221^{\prime}$ and Longitude $8^{\circ} 41.800^{\prime} \mathrm{E}$ ), Danmadahun (Latitude N12 $05.452^{\prime}$ and Longitude $8^{\circ} 40.418^{\prime} \mathrm{E}$ ) Yadakunya (Latitude $12^{\circ} 05.073^{\prime} \mathrm{N}$ and Longitude $8^{\circ} 38.823^{\prime}$ E). Jakara dam was constructed in 1976 and is situated in Wasai, Minjibir Local Government Area (LGA) in the North Eastern part of Kano metropolis about $41.5 \mathrm{Km}$ from the city centre. The area in terms of geology falls within the tip end of the Basement complex adjoining Chad formation, which is characterized by disappearing type of streams. Jakara dam is one of the most grossly polluted dam in West Africa, because during the dry season all the streams that feed it dry up with the exception of the major Jakara stream which sustain it. The water bodies contain muddy substrata and gentle flowing, low turbidity water with rich growth of algae and macrophytes.

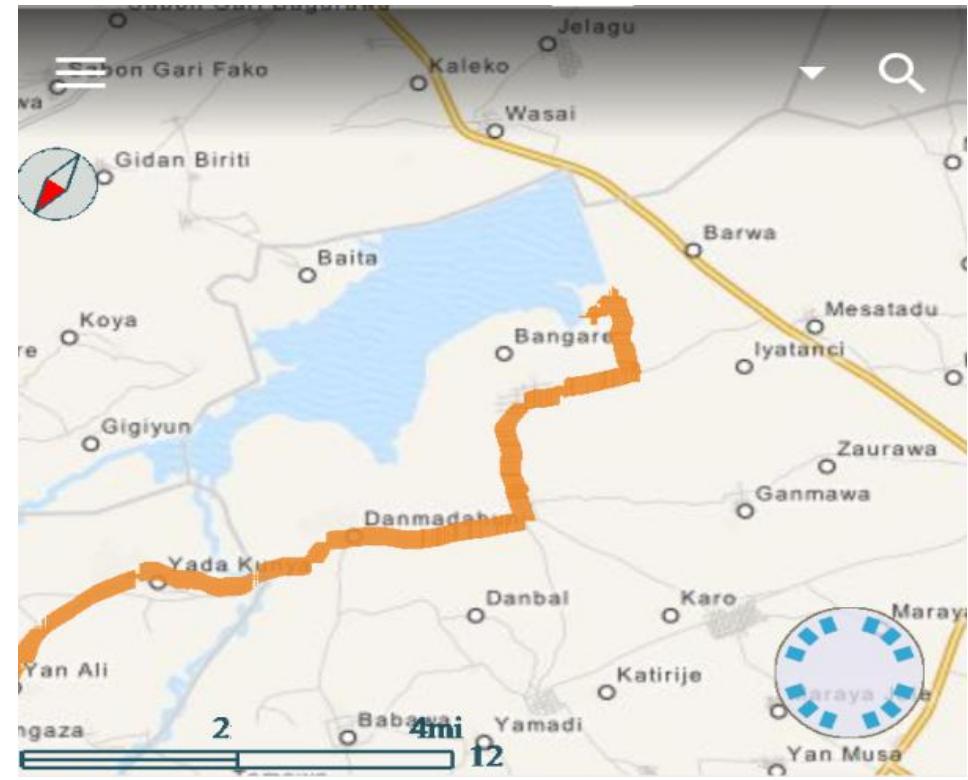

Fig.1: Map of Jakara dam

\subsection{Snail collection}

Five parts of Jakara dam were investigated for the presence of freshwater snails between October 2016 to January 2017. These parts are located on three local government areas of the state (Gezawa, Minjibir and Ungoggo). Snails were collected by hand picking only into a wide mouthed plastic container and brought to the laboratory. It was then sorted out into different species for further investigation. These snails were fed with lettuce during this study.

\subsection{Cercarial shedding}

Snails were separately placed in compartmented petridishes and exposed to artificial light (rechargeable lamp) for 2-3 hours to stimulate cercarial shedding, they were also exposed to sunlight on a sunny day (this is harmattan period in Kano). Few drops of water was then taken from the petridish and placed on a glass slide using a pipette and narcotized with neutral red to demobilize them before examination with a compound microscope for more detailed identification. Those snails that do not shed cercaria on the first day were re-exposed on the second day and those that shed cecariae were continuously exposed and observed under the microscope until the water in which they were placed was exhausted. Photomicrograph of the cercariae were taken using Toupview 3.1 digital camera fitted to the microscope through a USB and cercariae were identified using keys provided by Frandsen and Christensen (1984) and Key to cercarial identification.

\section{Results and discussion}

\subsection{Snails discovered}

All the study areas except one (Fako) were harbouring snail species. Two families of freshwater snails were discovered in Jakara dam (Fig.1). A total of 367 snails were collected out of which 200 (54.5\%) were different species of Bulinus and 167(45.5) were different Lymnea species. Kwata has the highest diversity with eight species, Bulinus species B. globosus morelet, B. reticulatus, B. truncatus rohlfsi, B truncatus truncatus 
Egypt, B jousseammei, B. succinoides and B. Camerunensis and only one Lymnea specie, Lymnea natalensis, no single live snail was encountered in the Fako part. Altogether Fourteen species of Lymnea were encountered from the dam. Lymnea species encountered were presumably identified as Peplimnea affinus ((Küster,1862), Lymnea (Pseudosuccina) columella, L. natalensis, Lymnaea olulla, L. tormentosa, L.auricularis rubiginosa. The names of some of the Lymnea species encountered cannot be determined. Bulinus species were not encountered in Bangare part of the dam. Kwata has the highest number of snails with 120 (32.7\%) followed by Danmadahun 91 (24.8), Bangare 89 (24.25) and the least 67(18.25).Out of the 167 Lymnea snails examined only 30(18\%) were infected (Table 2).

\subsection{Cercariae encountered}

Out of the 200 Bulinus snails collected (Table 3) only $12(6 \%)$ (Table 4) were infected. The overall prevalence of infection is $11.4 \%$. Twelve different types of cercaria were discovered but only nine of them were presumably identified as Virgulate, Ubiquita, Gymnocephalus, Amphistome, Echinostome ,Armatae cercaria ,Parapleurolophocercous cercariae, Ornatae and Fucocercus cercaria (Fig.4) (videos of swimming available), three of them cannot be identified.

Table 1: Frequency of occurrence of Lymnae species in different parts of the dam

\begin{tabular}{|c|c|c|c|c|}
\hline \multirow[t]{2}{*}{ Snail species } & \multirow[b]{2}{*}{ Danmadahun } & \multirow[b]{2}{*}{ Bangare } & \multicolumn{2}{|l|}{ Sites } \\
\hline & & & Kwata & Yadakunya \\
\hline L. natalensis & 12 & 13 & 6 & 9 \\
\hline P. affinus & 17 & 0 & 0 & 0 \\
\hline L.(Pseudosuccina) columella & 2 & 05 & 0 & 0 \\
\hline \multirow[t]{2}{*}{ Lymnaea ollula } & & & & 0 \\
\hline & 5 & 4 & 0 & 0 \\
\hline L. tormentosa L.auricularis & & & & \\
\hline \multirow{2}{*}{ rubiginosa } & 12 & 9 & 0 & 0 \\
\hline & 15 & 0 & 0 & 0 \\
\hline Austropeplea lessoni & 0 & 4 & 0 & 0 \\
\hline Radix ovata & 0 & 6 & 0 & 0 \\
\hline \multirow{3}{*}{$\begin{array}{l}\text { Lymnea peregra muller } \\
\text { Unknown (MI) }\end{array}$} & 0 & 9 & 0 & 0 \\
\hline & & & & \\
\hline & 0 & 2 & 0 & 0 \\
\hline Unknown K & 0 & 15 & 0 & 0 \\
\hline Unknown L & 0 & 5 & 0 & 0 \\
\hline Unknown M & 0 & 7 & 0 & 0 \\
\hline Unknown $\mathrm{N}$ & 0 & 10 & 0 & 0 \\
\hline Total & 63 & 89 & 6 & 9 \\
\hline
\end{tabular}

Table 2: Types of cercariae recovered from Lymnea species

\begin{tabular}{|c|c|c|c|}
\hline Lymnea species & $\begin{array}{l}\text { Number } \\
\text { collected }\end{array}$ & Number infected & Type of cercariae \\
\hline L. natalensis & 40 & 12 & $\begin{array}{l}\text { Virgulate, Ubiquita,Armatae } \\
\text { Unidentified } \\
\text { Gynocephalus }\end{array}$ \\
\hline $\begin{array}{l}\text { P. affinus } \\
\text { L.(Pseudosuccina) columella }\end{array}$ & $\begin{array}{l}17 \\
7\end{array}$ & $\begin{array}{l}3 \\
3\end{array}$ & $\begin{array}{l}\text { Unidentified, } \\
\text { gymnocephalus }\end{array}$ \\
\hline pervia(Austropeplea ollula $)$ & & & \\
\hline $\begin{array}{l}\text { L.tormentosa } \quad \text { L.auricularis } \\
\text { rubiginosa }\end{array}$ & (3) & 1 & 1utocertes \\
\hline & 21 & 1 & gymnocephalus \\
\hline $\begin{array}{l}\text { Austropeplea } \\
\text { Lessoni } \\
\text { Radix ovata }\end{array}$ & 15 & 1 & gymnocephalus \\
\hline $\begin{array}{l}\text { Lymnea peregra muller } \\
\text { Most infected }\end{array}$ & 4 & 0 & \\
\hline $\mathrm{K}$ & $\begin{array}{l}6 \\
9\end{array}$ & $\begin{array}{l}1 \\
2\end{array}$ & $\begin{array}{l}\text { Gymnocephaus } \\
\text { gymnocephalus }\end{array}$ \\
\hline
\end{tabular}




\begin{tabular}{llll}
\hline $\mathrm{L}$ & & & Amphistome,Echinostome \\
$\mathrm{M}$ & 2 & 2 & $\begin{array}{l}\text { Parapleurolophocercous, } \\
\text { gymnocephalus } \\
\mathrm{N}\end{array}$ \\
& & & gymnocephalus \\
& 15 & 2 & gymnocephalus \\
& 5 & 0 & gymnocephalus \\
\hline
\end{tabular}

Table 3: Bulinus species recovered from the study sites

\begin{tabular}{|c|c|c|c|c|}
\hline \multirow[t]{2}{*}{ Snail species } & \multirow[b]{2}{*}{ Kwata } & \multirow{2}{*}{$\begin{array}{l}\text { Study } \\
\text { Bangare }\end{array}$} & \multicolumn{2}{|l|}{ Sites } \\
\hline & & & Danmadahun & Yadakunya \\
\hline Bulinus globosus & 40 & 0 & 0 & 0 \\
\hline \multicolumn{5}{|l|}{ B. reticulates } \\
\hline B.truncatus rohlfsi & 8 & 0 & 3 & 5 \\
\hline $\begin{array}{lr}\text { B. } & \text { truncate }\end{array}$ & 15 & 0 & 3 & 13 \\
\hline $\begin{array}{l}\text { B. jousammei } \\
\text { B.succinoides }\end{array}$ & 9 & 0 & 8 & 3 \\
\hline & 19 & 0 & 3 & 11 \\
\hline & 13 & 0 & 8 & 11 \\
\hline & 10 & 0 & 3 & 15 \\
\hline Total & 114 & 0 & 28 & 58 \\
\hline
\end{tabular}

Table 4: Types of cercariae recovered from Bulinus species

\begin{tabular}{llll}
\hline Snail species & $\begin{array}{l}\text { Number } \\
\text { collected }\end{array}$ & $\begin{array}{l}\text { Number } \\
\text { infected }\end{array}$ & Type of cercariae \\
\hline Bulinus globosus & 40 & 12 & $\begin{array}{l}\text { Unidentified, unidentified fork- } \\
\text { tailed,Gymnocephalus, } \\
0\end{array}$ \\
$\begin{array}{l}\text { B. reticulates } \\
\text { B.truncatus rohlfsi } \\
\text { B. truncate }\end{array}$ & 16 & 0 & 0 \\
truncates Egypt & 31 & 0 & 0 \\
$\begin{array}{l}\text { B. jousammei } \\
\text { B. succinoides }\end{array}$ & 20 & 0 & 0 \\
$\begin{array}{l}\text { B. camerunensis } \\
\text { notal }\end{array}$ & 33 & & 0 \\
& 32 & 0 & 0 \\
\hline
\end{tabular}
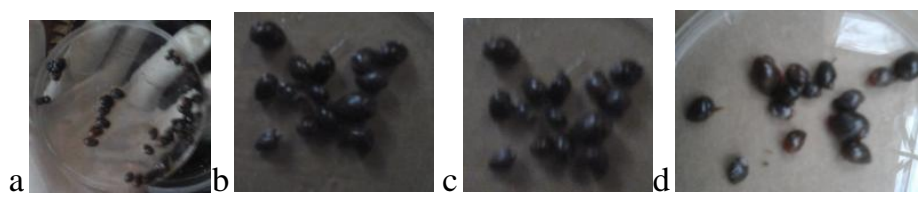

Fig.2 abcd : Bulinus species collected from Kwata
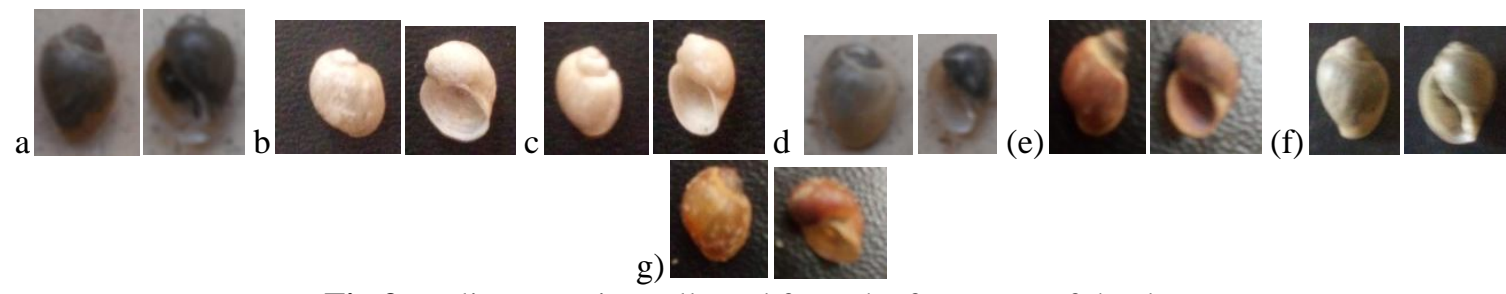

Fig.3: Bulinus species collected from the four parts of the dam

a.Bulinus globosus (b) B. Truncates truncates Egypyt,(c)B. Camerunensis, (d) B. jousammei gambia (e)B. reticulatus (f)B. truncatus rohlfsi (g) B. succinoides 


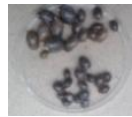

(b)
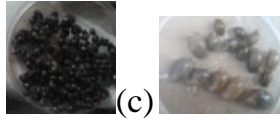

Fig.4a-c: (a) Lymnea and Bulinus species (c)Bulinus species(c) Lymnea species
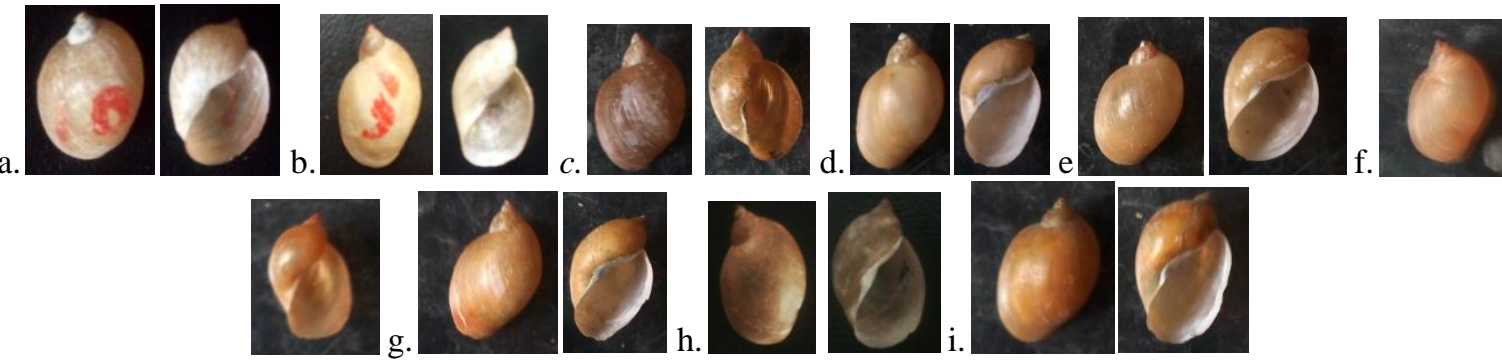

Fig.4: Identified Lymnea species a. Austropeplea lessoni (Deshayes, 1830)b.Lymnea natalensis c.Radix rubiginosa d. Peplimnea affinus e.Radix ovata f.L. pervia(Austropeplea ollula) g.Austropeplea tomentosa $\mathrm{h}$. Lymnaea (Pseudosuccina) columella i.Lymnea peregra muller

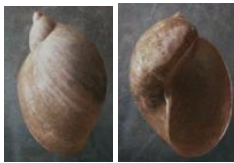

Fig.5: Most infected Lymnea specie (Bangare)
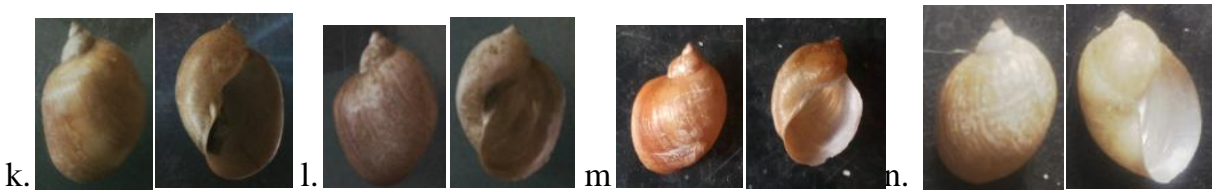

Fig.6: Unidentified lymnea species (Bangare)

(a)
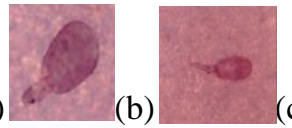

(c)

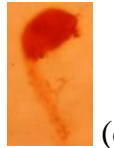

(d)
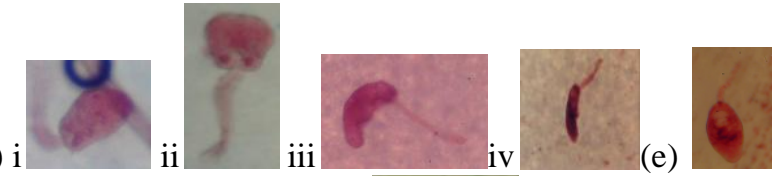

(f)
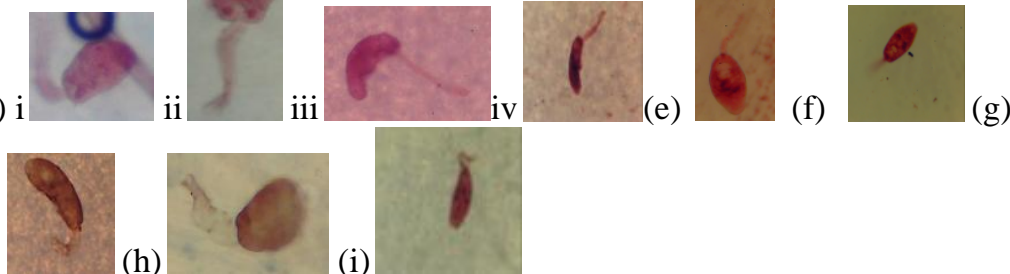

(h)
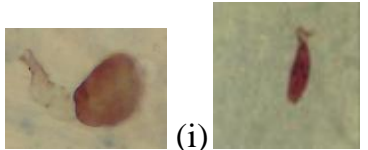

Fig.7a: Trematode cercariae recovered from Lymnea species (a)Virgulate cercaria(b)Armatae Xiphidiocercous cercariae (c)Ubiquita (d) Gymnocephalus (e)Echinostome (f) Parapleurolophocercous cercariae (g) Ornatae Cercaria (h) Fucocercus cercaria (i) Amphistome.

(a)
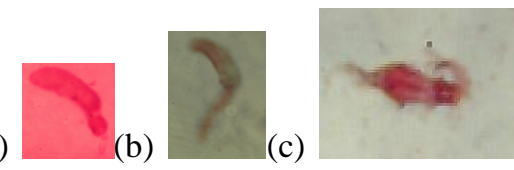

Fig.7b Unidentified cercariae (a) (b) (c)

This present study was motivated by the result of a previous study where many species of Bulinus were encountered in other parts of Jakara dam (Duwa, 2017) apart from the popular Wasai part (Kwata and Fako) in Minjibir local government area. In a previous study (Duwa and Oyeyi,2009;Duwa,2017) only two and three parts of the dam respectively were investigated and encountered only Lymnea natalensis as the only Lymnea specie, there was no report of other Bulinus species apart from Bulinus globosus in Wasai (Fako and Kwata) (Duwa,2017). This is also the first time different species of Lymnea were reported in Jakara dam, and even in Nigeria to the best of my knowledge. This may be the reason why identification was difficult. Further observation always reveal a new difference between two species that were initially grouped together as the same specie. These snail species have been classified based on morphology only. The different Lymnea species encountered in this study are twice larger than those Lymnea natalensis encountered in previous studies (physical observations). Whether Lymnaea natalensis species should be placed in the genus Lymnaea or in the 
genus Radix, formerly considered a subgenus of the first, remained unresolved for a long time (Bargues et al. 2001). Brown (1994) and Appleton (1996) refer to it as Lymnaea natalensis, but the molecular study of Correa et al. (2010) provides definite arguments for the use of Radix natalensis. This applies to other Lymnea species that are refered to as Radix. The identification of large Radix specimens from the Arabian Peninsula as Lymnaea (Radix) natalensis remains doubtful. Maybe the large Nigerian species will be named Lymnea (Radix) nigeria. Lymnaea mauritiana Morelet, 1875 is in recent literature also considered as a synonym of Radix natalensis. Pointier et al (2009) reported the presence of Lymnaea columella from Güigüe, state of Carabobo; L. Columella from El Valle, state of Mérida.There were two Lymnea species of different sizes and habitat preference in Danmadahun part of Jakara dam. Lymnea natalensis was found attached to the macrophyte, water hyacinth in muddy water with Bulinus species while the other and much bigger Lymnea species presumably identified as Lymnea tormentosa were picked from another 300 meters away, in clear water of pH7.2. The overall prevalence of infection is $11.4 \%$.Although the number of Bulinus species are more (54.5\%), Lymnea species (45\%) are the most infected in all the study sites with only $18 \%$ of the total Lymnea species (167) collected being infected while that of Bulinus is $6 \%$, these $18 \%$ from the Lymnea species were heavily infected, with one of them carrying more than one hundred cercaria and each slide containing different multiple infections.Although more Lymnea natalensis were infected than any other lymnea specie the most infected snail according to the number of cercariae found in the snail was the unidentified snail from Bangare and there are just two of them. These cercariae were presumably identified as Virgulate, Ubiquita, Gymnocephalus, Amphistome, Echinostome, Armatae cercaria ,Parapleurolophocercous cercariae, Ornatae and Fucocercus cercaria because the keys used did not exactly give the description of the type of cercariae encountered in this study. Ndifon (1990) reported the presence of Ornatae xiphidiocercaria; Virgulate xiphidiocercaria; Apharyngeate echinostome cercaria; Pleurolophocercous Echinostome cercaria; Collared non-echinostome cercaria; Gymnocephalous cercaria; Amphistome cercaria; Schistosomatium type cercaria; mammalian schistosome type brevifurcate cercaria; Echinocercous brevifurcate cercaria; Clinostomatid brevifurcate cercaria; Diplostomatid longifurcate cercaria; Strigeid longifurcate cercaria; and Furcocercous cercaria inflaticauda in Kano state but the full article was not available for comparism. Most of the cercariae were shed even without exposure to light. No live snail was encountered in the Fako part of the dam, this may be due to the fact that there are no macrophytes on which they can attach at the edges of water and also lay their eggs. The environment may not also be favourable for those species that does not need macrophytes as in the case of Danmadahun. Most of the snails collected from Bangare and Danmadahun were not attached to vegetation. Bangare (Gezawa LGA) part of Jakara dam is the most polluted part of the dam followed by Fako and Kwata in Wasai, Minjibir Local government area of the state.

\section{Conclusion}

These results provide a new insight into Lymnaeid snails in Jakara dam and in Nigeria as a whole. The emergence of these new Bulinus and Lymnea species may lead to a new trend in the transmission of both Schistosomiasis and Fasciolopsis because with time these new species can spread to other parts of the dam where it wasn't encountered before. The water body therefore poses a threat to human and animal health and therefore calls for an urgent snail control strategy.

\section{References}

[1]. Abebe R, Abunna F, Berhane M, Mekuria S, Megersa B, Regassa A. (2010) Fasciolosis: Prevalence, financial losses due to liver condemnation and evaluation of a simple sedimentation diagnostic technique in cattle slaughtered at Hawassa Munincipal abattoir. Southern Ethiopia Ethiop Vet J.;14(1):39-51.

[2]. A. A. Aliyu, I. A. Ajogi, O. J. Ajanusi and R. C. Reuben (2014) Epidemiological studies of Fasciola gigantica in cattle in Zaria, Nigeria using coprology and serology Journal of Public Health and Epidemiology Vol. 6(2), pp. 85-91

[3]. Bargues et al. (2001). Brown (1994) and Appleton (1996) In : PRIMEFACT 476, IDENTIFYING LIVER FLUKE SNAILS

[4]. Betterton, C., Ndifon, G.T., Tan, R.M., (1988b). Schistosomiasis in Kano State, Nigeria, II. Field studies on aestivation in Bulinus rohlfsi (Clessin) and B. globosus (Morelet) and their susceptibility to local strains of Schistosoma haematobium (Bilharz). Annals of Tropical Medicine and Parasitology 82: 571-579.

[5]. Duwa, M.R. and Oyeyi, T.I (2009) The role of Jakara dam in the transmission of schistosomiasis Bayero Journal of Pure and Applied Sciences, 2(1): $58-63$

[6]. Duwa R S (2017) Survey of Freshwater Snails on Three Parts of Jakara Dam, Kano State, Nigeria International Journal of Zoological Research ,13:20-25

[7]. Elelu N, Ambali A, Gerald C. Coles and Mark C. Eisler (2016) Cross-sectional study of Fasciola gigantica and other trematode infections of cattle in Edu Local Government Area, Kwara State, north-central Nigeria Parasites \& Vectors 9:470

[8]. Kebapci U, Yildirim MZ, Gülle İ, Öztop M, Çağlan DC.( 2012) The land snail fauna of Mut District (Mersin Province, Turkey). Turk J Zool.;36(3):307-18.

[9]. Lloyd , J; Boray, J and Campbell N (2007) Identifying liver fluke snails PRIMEFACT 476,NSW DPI

[10]. Michalik-Kucharz A. (2008) The occurrence and distribution of freshwater snails in a heavily industrialised region of Poland (Upper Silesia). Limnologica.;38(1):43-55. doi: 10.1016/j.limno..09.003

[11]. Mohammad I A Malekzadeh Y R Farhangpajuh V F (2011) Prevalence of Cercariae Infection in Lymnaea auricularia (Linnaeus, 1758 ) in NorthWest of Iran Veterinary Research Forum Vol: 2, No: 2, $121-127$

[12]. Ndifon, G.T., (1991) Human helminthiasis in the Tiga Lake Basin, Kano,Nigeria. Nigerian Journal of Parasitology 12: 81-84. 
[13]. Ndifon, G.T., Umar-Yahaya, A., 1990) Cercariae of freshwater snails in Kano, Nigeria. Nigerian Journal of Parasitology 11: 6975.

[14]. Frandsen, F. / Christensen, N.Ø. (1984) An introductory guide to the identification of cercariae from African freshwater snails with special reference to cercariae of trematode species of medical and veterinary importance Acta Tropica 4L 181-202 Danish Bilharziasis Laboratory. Charlottenlund. Denmark

[15]. Odening, K and Samnaliev, P (1987) A New Amphistome Cercaria from Lymnaea truncatula in Europe Ann. Parasitol. Hum. Comp., 62, $\mathrm{n}^{\circ} 2$, pp. 117-121

[16]. Ofoezie,Ifeanyi Emmanuel (2002)Human health and sustainable water resources development in Nigeria: Schistosomiasis in artificial lakes Natural Resources Forum 26, 150-160

[17]. Phiri AM, Phiri IK, Sikasunge CS, Monrad J. (2005) Prevalence of fasciolosis in Zambian cattle observed at selected abattoirs with emphasis on age, sex and origin. J Vet Med B Infect Dis Vet Public Health.;52(9):414-6.

[18]. Pointier, JP; Noya, O; de Noya Alarcón B; A Théron (2009)Distribution of Lymnaeidae (Mollusca: Pulmonata), intermediate snail hosts of Fasciola hepatica in Venezuela Mem Inst Oswaldo Cruz, Rio de Janeiro, Vol. 104(5): 790-796

[19]. Rouhollah Valipour Nouroozi (2015) Identification of Medically Important Snails of Miangran Lake in Izeh, Khuzestan Province of Iran Avicenna J Clin Microb Infec. 2(4): e30460.

[20]. Umar A G, Nwosu CO, Philip HR (2009). Seasonal prevalence and economic importance of Bovine fascioliasis in Jalingo Abattoir, Taraba State. Nigeria Nig Vet J.;30:44-50.

[21]. Van Damme, D. (2016). Radix natalensis. The IUCN Red List of Threatened Species: e.T165761A42436205

[22]. WHO, (1998)“Triclabendazole and fascioliasis - a newdrug to combat an age-old disease," Fact Sheet no. 191 Seasonal Prevalence of Fasciola Gigantica in Slaughter Cattle in Major Abattoirs in Port Harcourt. Gboeloh, LeBari Barine Advances in Agriculture, Sciences and Engineering Research http://www.ejournal.sedinst.com

[23]. http://www.elrincondelmalacologo.com/Web\%20fotos\%20agua\%20dulce/Lymnaeidae.htm 